\title{
Acceleration of Land Certification with Unmanned Aerial Vehicle in Cisumdawu Toll Road Construction Area
}

\author{
Bambang Edhi Leksono, Agoes Soewandito Soedomo, Levana Apriani, Nanin Trianawati Sugito and Atifah \\ Rabbani \\ Surveying and Cadastre Research Group, Geodesy and Geomatics Engineering, Faculty of Earth Science and Technology, \\ Bandung Institute of Technology Bandung, Indonesia.
}

Received: 2018-04-06 Accepted: 2019-03-28

Keywords:

certification

Cisumdawu toll road; UAV.

Corespondent Email: aprianilevana@gmail.com

\begin{abstract}
The construction of the Cisumdawu Toll Road is carried out to overcome congestion on Cadas Pangeran Road and as quick access to Kertajati International Airport. At the time of construction, problems were found, namely land acquisition that had not been completed due to the absence of land certificates, whereas before obtaining the certificate, land measurements must be carried out first. The purpose of this study is to measure land parcels using the help of Unmanned Aerial Vehicle (UAV). The result is a digitalized land parcel map on a photo map in Pamekaran Village, namely the village affected by the construction of the Cisumdawu toll road. It is expected that the presence of land parcel maps can accelerate the process of land acquisition with minimal conflict.
\end{abstract}

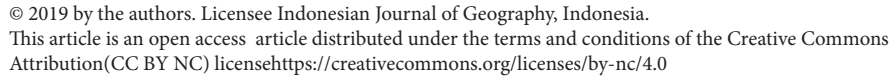

\section{Introduction}

The Cisumdawu Toll Road (Figure 1) is a $60 \mathrm{~km}$ highway part of the Trans Java Toll Road in West Java connecting the Cileunyi - Sumedang - Dawuan or Padaleunyi Toll Road with the entire Palimanan - Kanci Toll Road using an area of 825 ha. The construction of Cisumdawu Highway is expected to reduce the congestion level of Sumedang - Bandung route and the road load on Cadas Pangeran Road which is famous for a landslide. It is just that there is also a negative impact of the reduced agricultural land area of 750 ha, and can reduce the incomes of people around Cadas Pangeran Road.

In addition to the above problem, the construction of toll roads is often found problems of land acquisition. Generally, land acquisition is hampered due to uncertainty over own land covering land price, release time, and ownership status. In the construction of Cisumdawu Toll Road, land acquisition alone has been completed by about $35 \%$. It is just that construction cannot be done some lands have not been released. Thus, the necessary acceleration to conduct land acquisition, thus the construction of Cisumdawu Toll

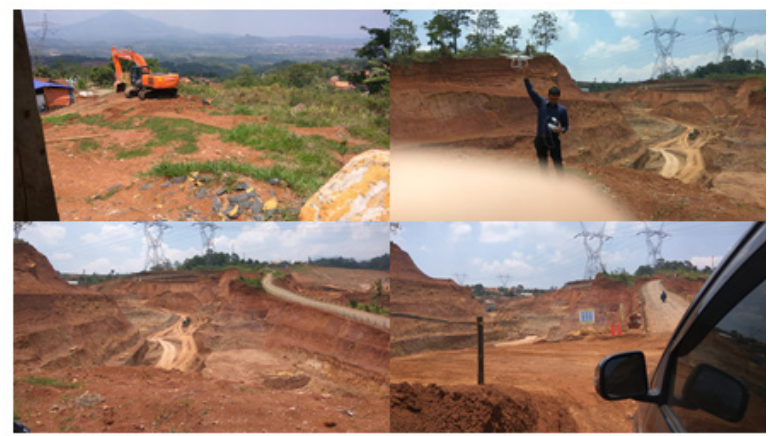

Figure 1. Cisumdawu Toll Road Construction
Road can also be quickly resolved. One factor which can be an obstacle to land acquisition is the absence of land certification. Uncertified land will be difficult to be released because the ownership is not clear and will reduce the value of the land. This will be a loss for both parties, namely the government as a buyer and the community as a seller. One solution offered to help accelerate certification is mapping with UAV.

Using UAV can generate large-scale maps with more affordable survey cost, and also avoid conflicts due to direct measurement. Previously, research was conducted on the need for cadastral maps in Switzerland using UAVs, the result was fast data acquisition and low flying altitude, the results obtained were quite accurate and met the precision specifications of cadastral surveys in Switzerland. Using UAVs, height data and objects in three dimensions are also obtained (Manyoky et al, 2011). Planimetric accuracy using UAVs for land registration maps in an effort to accelerate land registration in Indonesia has also been studied and its accuracy meets the error tolerance listed in Technical Guidelines for PMNA / Head of BPN No.3 in 1997, which amounts to $4-12 \mathrm{~cm}$ (Gumeidhidta, 2017). There is also research that proves that the use of UAVs to update cadastral maps can identify objects more than $80 \%$ of natural objects and $90 \%$ of man-made objects, and $50 \%$ cheaper compared to terrestrial measurements (Kedzierski et al, 2015). Therefore, it can be concluded that UAVs can be used for cadastral mapping or land registration.

Before toll road construction, land acquisition must be done. Land acquisition is the process by which the government forcibly acquires private property for 
public purpose without the consent of the land-owner. It is thus different from a land purchase, in which the sale is made by a willing seller (Sridhar \& Mandyam, 2009). For the toll road construction, in the area where the toll road is going to be built, the land is needed to be acquired. In Indonesia, the government facilitating land availability before the start of toll construction. It stated on Law of the Republic of Indonesia Number 2 of 2012 concerning Acquisition of Land for Development in the Public Interest. (Sihombing, 2014). However, this new law could help to accelerate the land acquisition process. Based on the law, in order the acquired land, the government has to follow a process of declaring the land to be acquired, notify the interested persons, consult to the public about the development plan and acquire the land after paying due compensation. Land acquisition process is not easy and always full of pros and contras, that is why Jasa Marga stated that the two biggest risks in Indonesia's toll road industry are a risk of land acquisition and risk of missed traffic forecast (Jasamarga, 2017)

After land acquisition, it will be needed land registration to get the Land Title Deed. A Land Title Deed is known in Indonesia as a "Sertifikat Tanah" and is always accompanied by a Survey Certificate known as "Surat Ukur" that documents the location and dimensions of the land. Based on UUPA, land transfers and land title deeds are drafted by a Land Deed Official known as "Pejabat Pembuat Akte Tanah" or PPAT. PPAT are very commonly also Notaries and are easy to find even the smallest of towns in Indonesia. The vast majority of land in Indonesia is in fact not registered at the BPN and is held under the traditional title "Hak Adat". Occasionally, provincial governments will carry out publicity campaigns urging people, especially those in non-urban areas, to survey and register their land. However, this can be very problematic indeed, as lands are often "owned" by extended families who extent is difficult (and sometimes even dangerous) to actually clearly define. Serious family disputes can be triggered by the very suggestion (Muazzin, 2014). Fortunately, most lands in areas of interest to foreigners and PMA

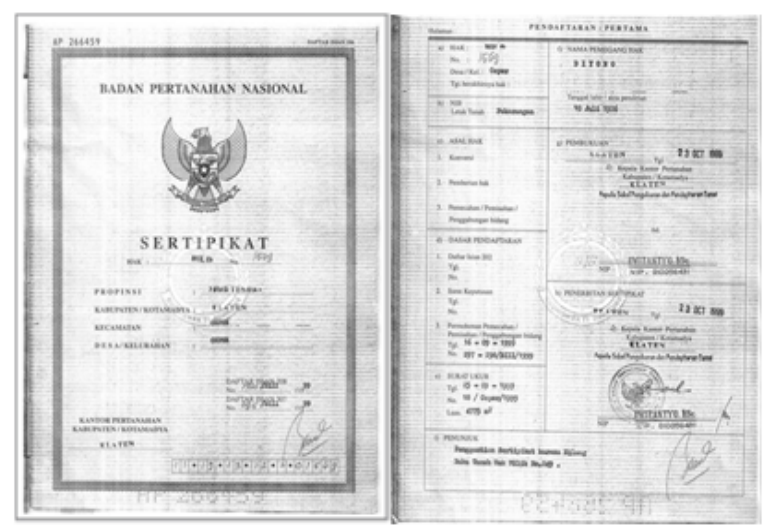

Figure 2. Land Title Deed (Dean, 2003) companies will already have some form of clear land title. An example of a Land Title Deed can be seen in Figure 2.

\section{Methods \\ Preparation}

In this study, data acquisition uses the remote sensing method, especially aerial photography, because it does not touch the object at all. The tool used is the DJI Phantom 4 series drone. In addition, aerial photography requires a Ground Control Point (GCP) and/or Independent Control Point (ICP) to rectify. GCP and ICP are measured using GPS Geodetic Trimble R4 series. Processing data using an ASUS A456U laptop equipped with Agisoft Photoscan software to process the aerial photo, Drone Deploy to determine the flight path, Trimble Business Center to process GPS data, and ArcGIS to digitize photo maps.

In addition to the preparation of tools, an area of interest (AOI) is planned for 361 hectares. AOI is located in Pamekaran Village, which is one of the villages affected by land acquisition, the land acquisition process has been completed. The number of GCP and ICP is determined. GCP functions as an allied point connecting between the map coordinate system and the photo and ICP coordinate system serve to determine the accuracy of an aerial photograph (Husna et al, 2016). GCP is planned for 15 points and ICP as many as 18 points, it is shown in Figure 3. The flight path is also starting to be planned with $65 \%$ front overlap and $70 \%$ side overlaps, flying altitudes ranging from 800 - 1000 $\mathrm{m}$, it is shown in Figure 4.

This research is using Low Altitude, Short Endurance (LASE) type of UAV or drone because the location of the toll road is easy to field and only need 1-2 hour for capturing it. Although drone is not highend technology, the drone can be useful if the user needs high spatial resolution data without the obstacle from cloud cover which is obtained by using satellite image. Drone is also effective for low-cost surveying.

\section{Data Acquisition}

After planning, the next step is to measure with GPS Geodetic to obtain GCP and ICP coordinates that have been determined and made mark in the field, GCP is taken using a static method, while ICP is taken using the real-time kinematic method. The last is taking an aerial photograph using quadcopter (four propellers) drone which follows a flight plan. Data is taken based on the flyway plan that has been made. A survey with UAV is shown in Figure 5, Figure 6 and Figure 7.

\section{Data Processing}

After conducting a survey, then the result of UAV is processed with software for geometric correction, in order to coordinate the aerial photograph in accordance with global coordinates. From the results of geometric correction and then done the mosaic on all the photos, 


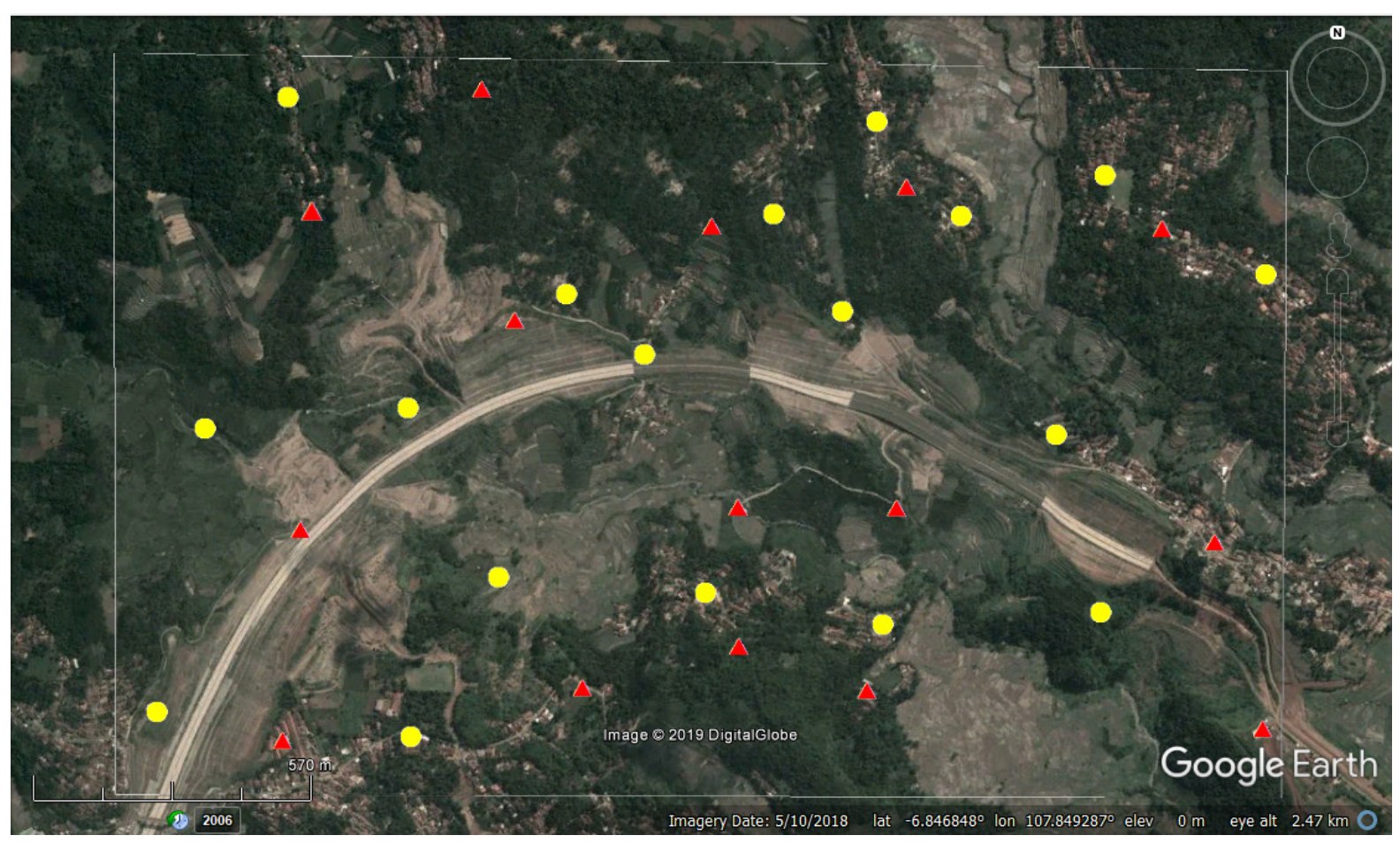

Figure 3. AOI (White Line) and GCP (Red Triangle) \& ICP (Yellow Circle) Plan

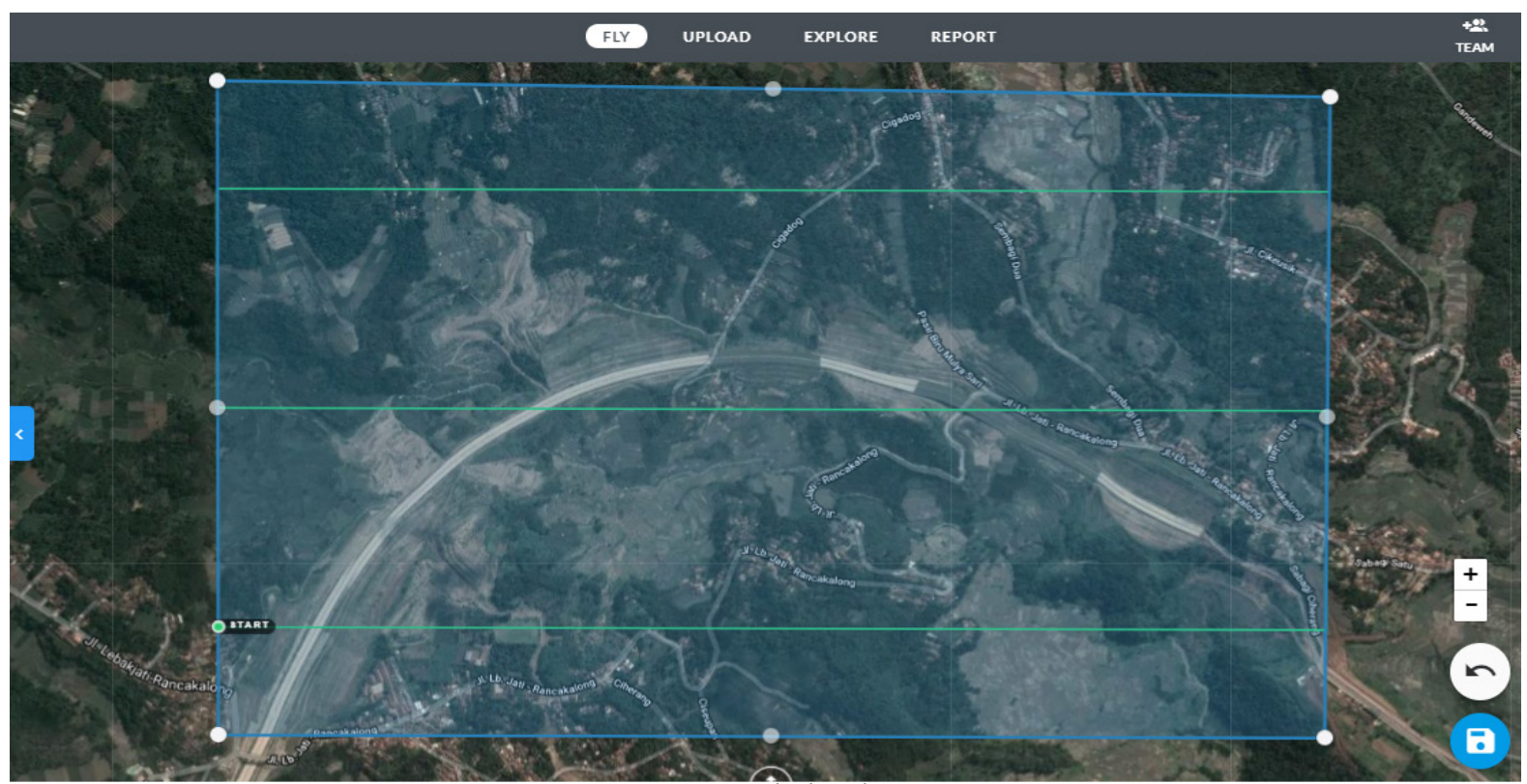

Figure 4. Flight Plan

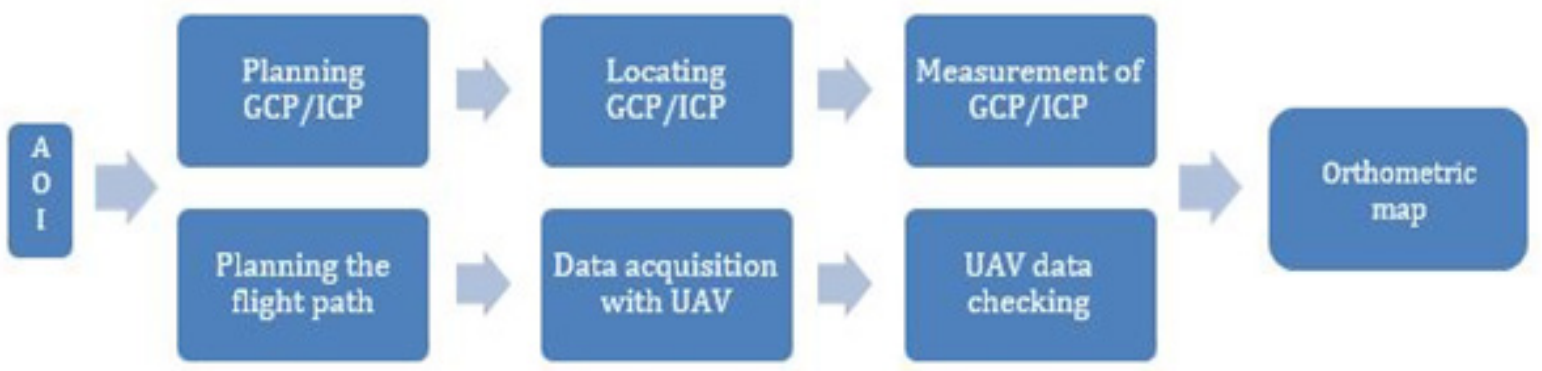

Figure 4. UAV Diagram Flow 

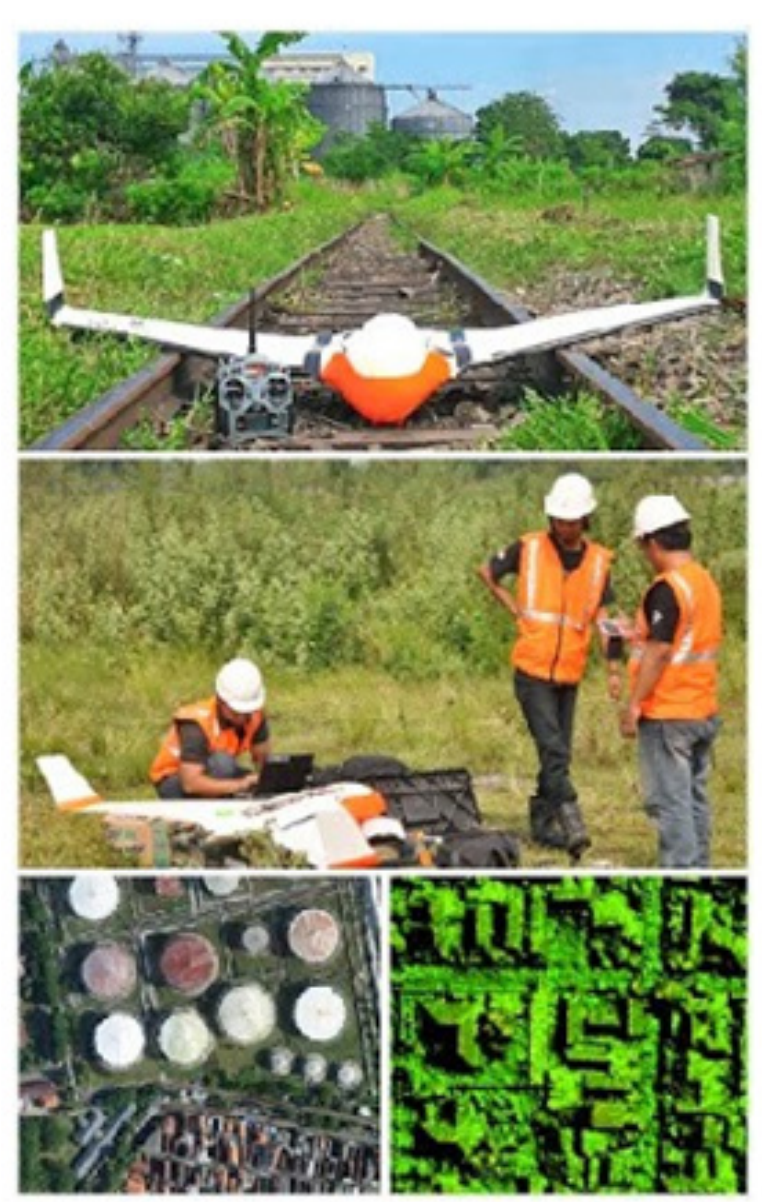

Figure 5. Illustration of UAV Survey (Jasa Survey

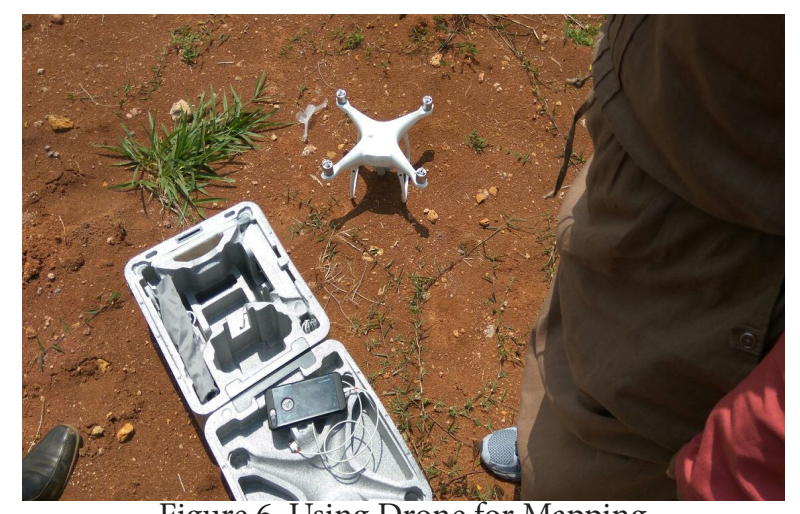

Figure 6. Using Drone for Mapping

it aims to unify the photo and ready to be processed to become the base map which is shown in Figure 8 .

When processing aerial photo data, GCP and ICP data are also processed using the Trimble Business Center, then rectifying the model. Comparison of the results of GPS measurements and rectification in GCP and ICP is shown in Table 1 and Table 2.

After rectification, the next step is land parcel digitizing. Land parcels are made referring to the data obtained from the Cisumdawu Toll Road Inventory and Land Acquisition Work Units. The land parcels taken are land parcels that will be affected by the construction of the Cisumdawu toll road and special data held by the community, not the public facilities data. The process is shown in Figure 9.

After the process digitizing, done matching data with data given. Matching data is done by giving the land parcel number. Land parcel matching is intended for pooling of parcel data with textual. data related to the plot. Land parcels are also matched with peta.bpn. go.id to find out their legal status, whether certified or not in Figure 10.

\section{Result and Discussion}

The result is obtained in the form of a photo map with Pamekaran Village. The information that can be displayed on the Pamekaran Village is the land area and the legal status. There is information related to land acquisition, but the information cannot be displayed because it is confidential. The map displayed on Figure 11.

From the results of the processing calculated Root Mean Square Error (RMSE) to find out whether the geometric quality of aerial photos is good. If the RMSE value is $<1$ pixel, no further rectification is necessary. Conversely, if the RMSE is $>1$ pixel, then do the rectification process (Subakti, 2017). The results of the RMSE calculation are shown in Table 3.

Value of 1 pixel in the photo is equal with $0.25 \mathrm{~m}$ in the real world, thus it will not be needed rectification again. In the photo, there is still relief displacement because DEM data is not provided. In this case, DEM data is not calculated because a photo map is needed for land parcel, that is not related to elevation data.

Land acquisition is a preliminary task of road development projects. For proper highway network, especially for expand the existing roads and construct new roads, highways, and expressways, private lands in both sides of the roads should be acquired. Based on Law of the Republic of Indonesia Number 2 of 2012 Concerning Acquisition of Land for Development in the Public Interest, The Government and the Regional Governments guarantee the availability of land in the Public Interest and funding. Furthermore, it is stated that the acquisition of land shall be performed through planning involving all the guardians and stakeholders.

Land in the Public Interest shall be used for the development of the national defense and security; public roads, toll roads, tunnels, rail lines, railway stations, and railway operating facilities; etc. The Entitled Party must release his/her land during the implementation of the Acquisition of Land in the Public Interest upon the giving of Compensation or under a final and binding court decision. The giving of Compensation for Objects of the Acquired Land shall be directly made to the Entitled Party. The giving of Compensation must in principle be given directly to the Party Entitled to Compensation.

Land acquisition needs legal instruments which are carried out in three ways, first is releasing land 
Indonesian Journal of Geography, Vol. 51 No. 1, April 2019: 1- 8

Table 1. GCP XY Coordinates

\begin{tabular}{rrrrr}
\hline GCP Name & XGPS $(\mathrm{m})$ & YGPS $(\mathrm{m})$ & XMODEL $(\mathrm{m})$ & YMODEL $(\mathrm{m})$ \\
\hline GCP01 & 814961.6973 & 9242655.2139 & 814961.7091 & 9242655.1118 \\
GCP02 & 815012.2388 & 9242081.0750 & 815012.1012 & 9242081.0216 \\
GCP03 & 815012.3929 & 9241796.9332 & 815012.3103 & 9241796.9429 \\
GCP04 & 814070.6024 & 9241610.5383 & 814070.6842 & 9241610.4288 \\
GCP05 & 814137.4730 & 9242690.8283 & 814137.5909 & 9242690.6896 \\
GCP06 & 814110.1597 & 9242040.9590 & 814110.1397 & 9242041.0729 \\
GCP07 & 815890.1941 & 9242644.3758 & 815890.1275 & 9242644.2270 \\
GCP08 & 815994.7635 & 9242003.9076 & 815994.7471 & 9242003.9769 \\
GCP09 & 814554.3532 & 9242465.5806 & 814554.2818 & 9242465.6270 \\
GCP10 & 814689.4076 & 9241714.2804 & 814689.4735 & 9241714.2694 \\
GCP11 & 814489.1791 & 9242937.3753 & 814489.1037 & 9242937.2978 \\
GCP12 & 816091.4046 & 9241622.4257 & 816091.4951 & 9241622.5240 \\
GCP13 & 815363.8125 & 9242732.5355 & 815363.7871 & 9242732.4123 \\
GCP14 & 815339.2999 & 9242077.5387 & 815339.4406 & 9242077.6553 \\
GCP15 & 815276.0906 & 9241705.5258 & 815276.0417 & 9241705.6573 \\
\hline
\end{tabular}

Table 2. ICP XY Coordinates

\begin{tabular}{rrrrr}
\hline ICP Name & XGPS $(\mathrm{m})$ & YGPS $(\mathrm{m})$ & XMODEL $(\mathrm{m})$ & YMODEL $(\mathrm{m})$ \\
\hline ICP01 & 814090.0530 & 9242922.3032 & 814090.1706 & 9242922.2425 \\
ICP02 & 814822.2188 & 9242392.8147 & 814822.0726 & 9242392.6920 \\
ICP03 & 814945.0503 & 9241905.7068 & 814944.9262 & 9241905.7300 \\
ICP04 & 815310.3116 & 9241838.7964 & 815310.3634 & 9241838.8850 \\
ICP05 & 815670.0174 & 9242223.9703 & 815670.1619 & 9242223.9170 \\
ICP06 & 815230.8644 & 9242478.4384 & 815230.7331 & 9242478.4595 \\
ICP07 & 815090.1436 & 9242677.8393 & 815090.0416 & 9242677.7050 \\
ICP08 & 815303.8632 & 9242865.1249 & 815303.9953 & 9242865.2518 \\
ICP09 & 814518.5406 & 9241940.0693 & 814518.4685 & 9241940.1513 \\
ICP10 & 814335.9915 & 9241615.8383 & 814336.1409 & 9241615.8464 \\
ICP11 & 815476.5391 & 9242671.2289 & 815476.4785 & 9242671.1626 \\
ICP12 & 815773.7558 & 9242752.7290 & 815773.8059 & 9242752.6902 \\
ICP13 & 814333.9419 & 9242286.5535 & 814333.7968 & 9242286.6586 \\
ICP14 & 815759.5810 & 9241860.9354 & 815759.6801 & 9241860.8004 \\
ICP15 & 816104.1175 & 9242548.4233 & 816104.0422 & 9242548.5609 \\
ICP16 & 813915.3531 & 9242247.1557 & 813915.3774 & 9242247.1826 \\
ICP17 & 813812.9217 & 9241669.1034 & 813813.0417 & 9241668.9966 \\
ICP18 & 814662.0506 & 9242517.1030 & 814661.9884 & 9242517.2503 \\
\hline
\end{tabular}

Table 3. RMSE Calculation Result

\begin{tabular}{rr}
\hline Name & RMSE \\
\hline GCP X RMSE & 0.080722145 \\
GCP Y RMSE & 0.099506881 \\
GCP XY RMSE & 0.128131511 \\
ICP X RMSE & 0.011575999 \\
ICP Y RMSE & 0.008848713 \\
ICP XY RMSE & 0.142915050 \\
\hline
\end{tabular}

Source: Data processing rights (Law of the Republic of Indonesia Number 2 of 2012 Concerning Acquisition of Land for Development in the Public Interest), revoking land rights (Law of the Republic of Indonesia Number 20 of 1961 Concerning Revocation of the Right to Land and Property Objects), and agreement between both parties concerning land value (Firmansyah \& Tisnanta, 2015).

To provide the legal instruments, it needs parcel mapping using UAV aims to speed up the certification process. The certification process is a very important process in the sale and purchase of land, with the 


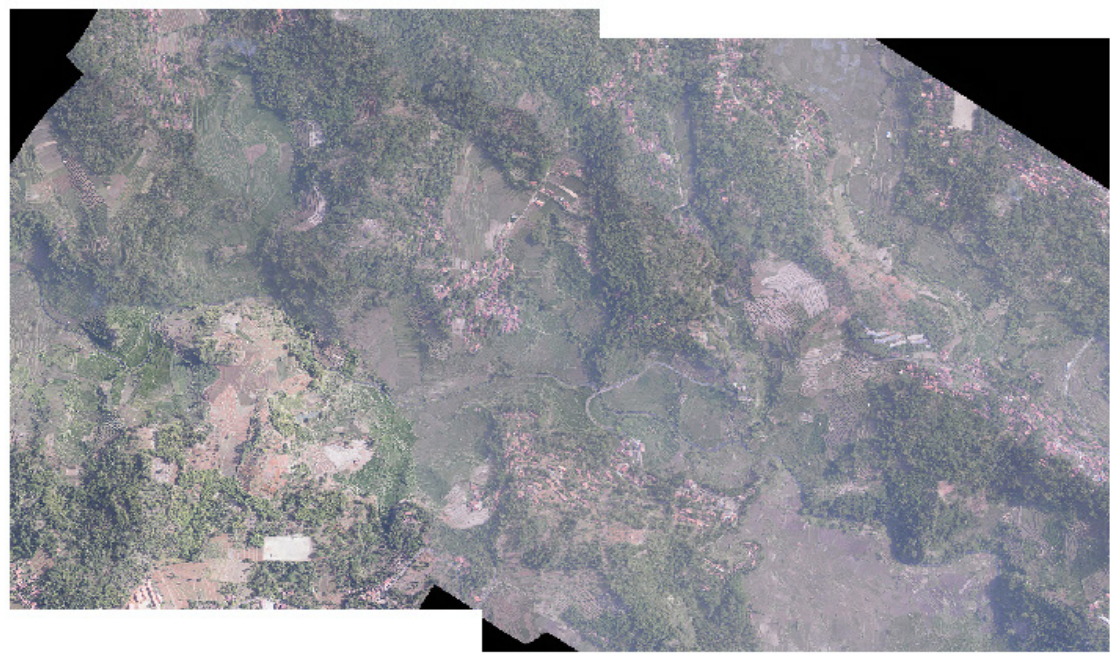

Figure 8. Photo Map

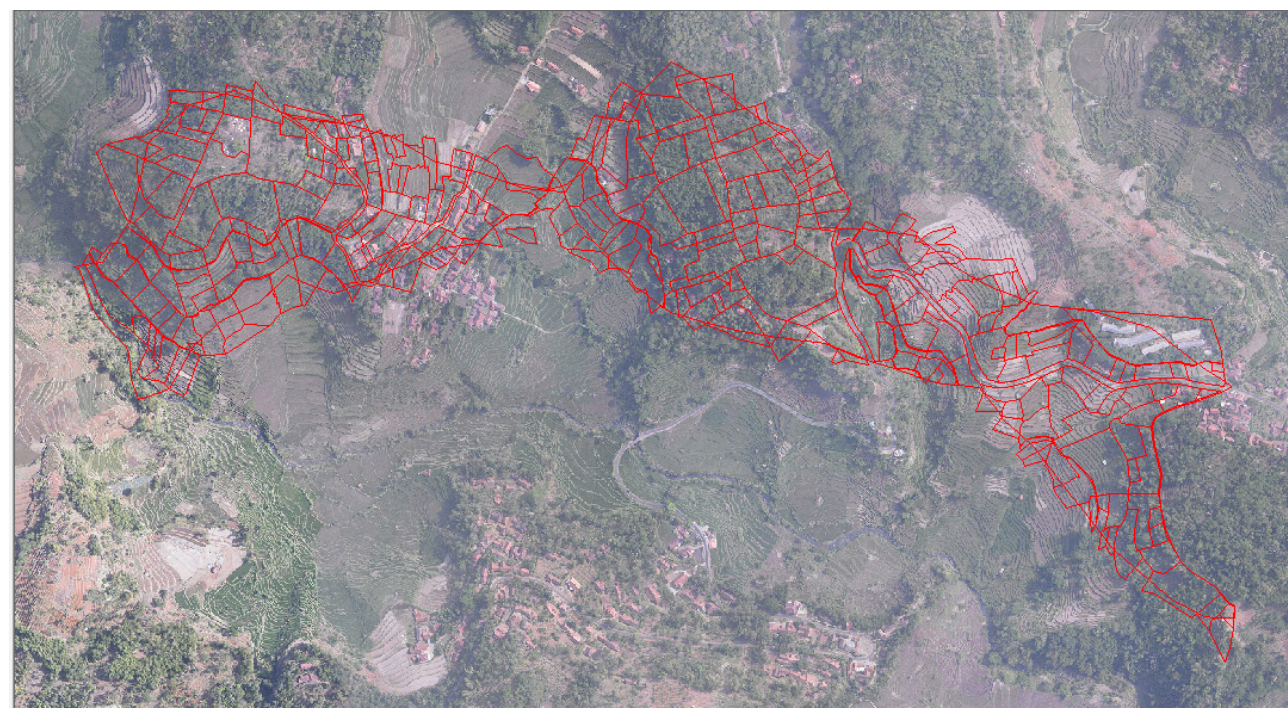

Figure 9. Land Parcel Digitizing

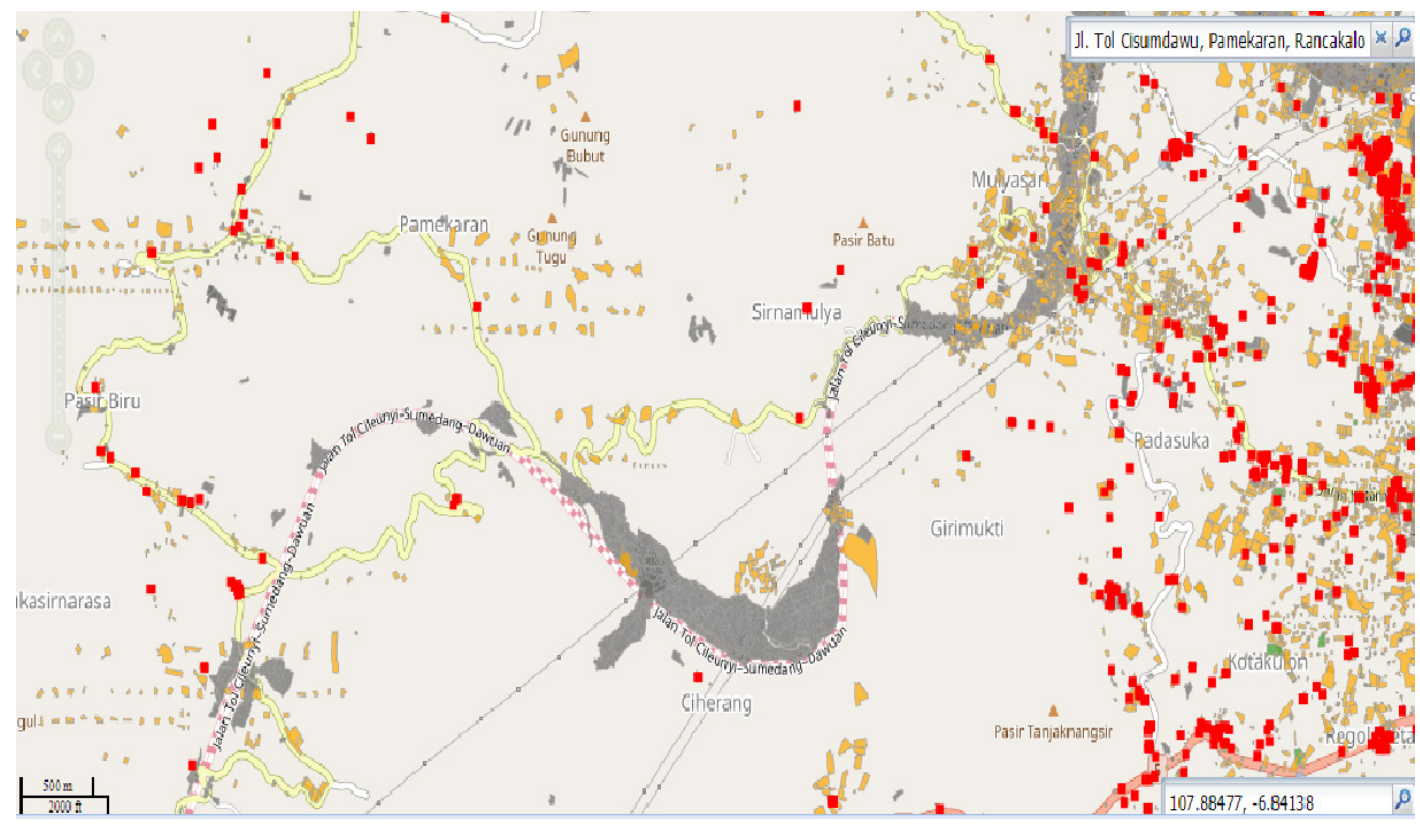

Figure 10. Land National Agency Online Map 


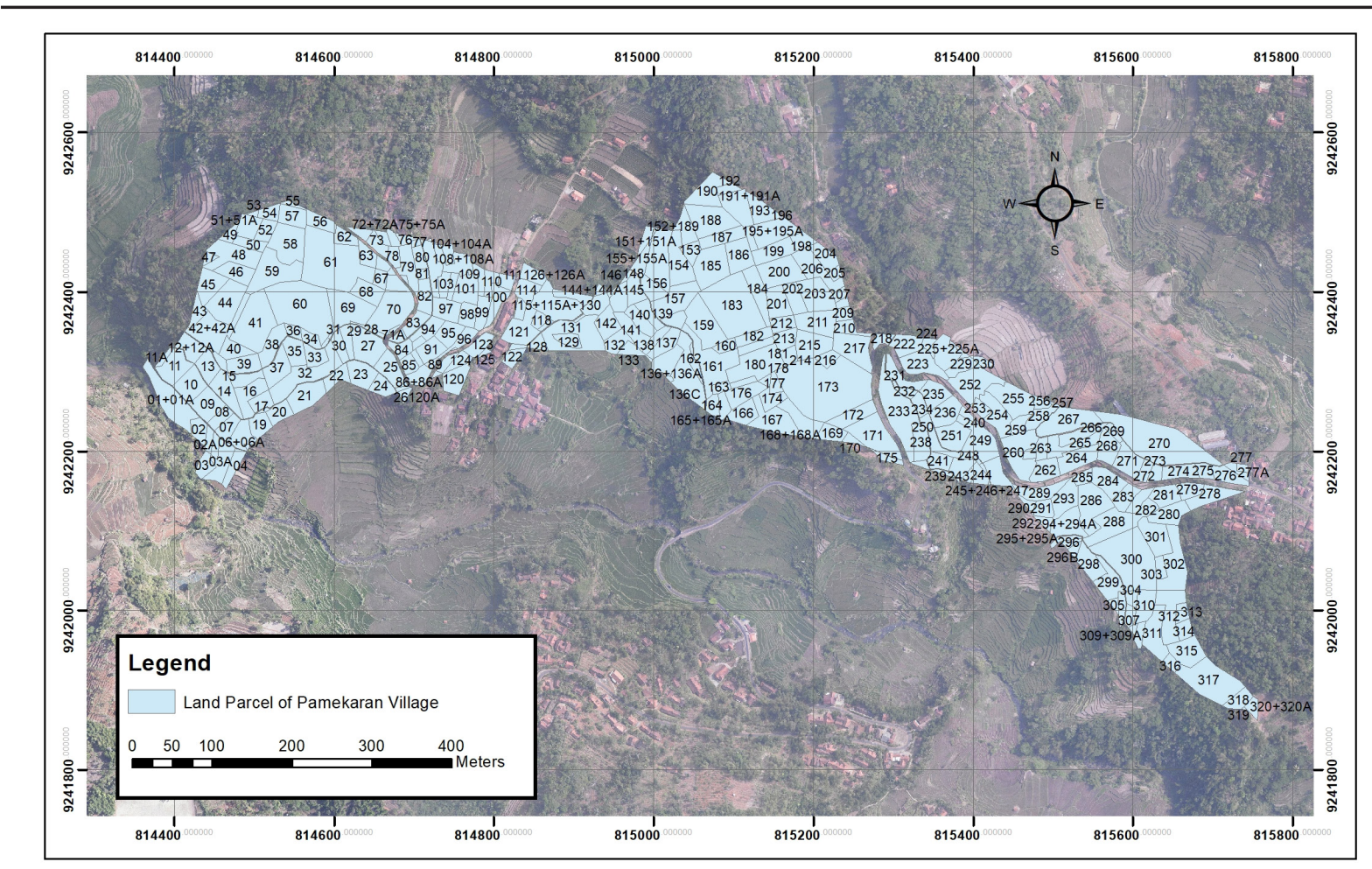

Figure 11. Land Parcel Map

certificate of legal certainty will be guaranteed. When viewed from the research area on the toll road, the certification is necessary to buy the land of citizens who will be "sacrificed" for the public interest, thus there is no land dispute because the certificate already shows that the land is already owned by the government. Choosing UAV as technology is to overcome the difficulties of mapping terrestrially or directly to the object. In general, the measurement of land using real-time kinematic, only when entering into densely populated settlements, the GPS signal cannot be caught. This will result in less accurate size results. UAV is also more flexible and efficient when it comes to capturing an image, thus plenty of cadastral mapping start using UAV as data acquisition (Manyoky, et al, 2011).

To more accelerating certification, the government can assign head of village or district as temporary land deed official (Pejabat Pembuat Akta Tanah Sementara - PPATS). Consideration of the appointment of the head of the village or district as the official registration of temporary land deeds is to replace the role of land deed official in urban areas. The construction of the Cisumdawu toll is located in a rural area which is far enough to the downtown. The community can register their land to the head of a village or district who has been appointed as temporary land deed official. Although the head of sub-district or urban village has no experience as a land deed official, pursuant to Article 18 Paragraph 2 of the Regulation of the Head of the National Land Agency of Republic of Indonesia Number 1 of 2006 Concerning The Provisions of the Implementation of the Government Regulation Number 37 of 1998 on The Rule of Office of the Land Deed Official that head of village or district must follow the education and training conducted by the National Land Agency in cooperation with professional organizations land deed official (Nurhayati \& Erren, 2013).

UAV map photos can also help the sub-district or village head to see the land use, the land area, and the land parcel boundary, thus saving the time and effort normally used for the direct survey. With the help of UAV photo map also, temporary land deed official can integrate the textual data contained in the certificate into the map, making it easier in the process of data inventory. The benefit for the people who have already certified the land is the value of the land to rise and for the government as the buyer of the land is to accelerate the process of developing the toll road because it does not need to be difficult anymore in conducting land certification.

\section{Conclusion}

Mapping with UAV can be done for cadastre problem one of them is certification. By using a photo map of UAV, land parcels can be mapped and assist in data collection of land that can be released for the further certificate. The results of this study are photo maps in the land acquisition area of the Cisumdawu toll road, precisely in Pamekaran Village, with a resolution of $0.25 \mathrm{~m}$ and a fairly good level of accuracy based on RMSE. The next result is parcel data obtained from digitalized results. The novelty of this research is that UAV is used to assist in measuring land acquisition areas, which are conflict-prone areas. 


\section{Acknowledgment}

We would like to thank the Institute for Research and Community Services of Bandung Institute of Technology for funding this research and also thank Cisumdawu Toll Road Inventory and Land Acquisition Work Units for providing data and information.

\section{References}

Dean, Gary. (2003). Indonesian Land Law and Foreign Ownership of Land.

Firmansyah, A., \& Tisnanta, H. (2015). Land Acquisition in Accelerating and Expansion of Indonesia's Economic Development Program: A Review of Law, Moral and Politic Relations. South East Asia Journal of Contemporary Business, Economics, and Law, 7(4), 1823.

Gumeidhidta, I.A. (2017). Analysis Ketelitian Planimetri Orthopoto Memanfaatkan Teknologi Unmanned Aerial Vehicle (UAV) Untuk Pembuatan Peta Dasar Pendaftaran. Theses. Teknik Geomatika, Universitas Gadjah Mada.

Husna, S.N., Subiyanto, S., \& Hani'ah. (2016). Penggunaan Parameter Orientasi Eksternal (Eo) untuk Optimalisasi Digital Triangulasi Fotogrametri untuk Keperluan Ortofoto. Jurnal Geodesi Undip. 5(4), 178-187.

Jasamarga. (2017). The Biggest Risks in Indonesia's Toll Road Industry.

Kedzierski, M., Fryśkowska, A., Wierzbicki, D., \& Deliś, P. (2015). Cadastral Mapping Based on UAV Imagery. 15th International Scientific and Technical Conference 'From Imagery to Map: Digital Photogrammetric Technologies', $12-15$.
Manyoky, M., Theiler, P., Stendler, D., \& Eisenbeiss, H. (2011). Unmanned Aerial Vehicle in Cadastral Applications. International Archives of the Photogrammetry, Remote Sensing and Spatial Information Sciences, XXXVII-1/ C22(38), 57-62.

Muazzin. (2014). Hak Masyarakat Adat (Indigenous Peoples) atas Sumber Daya Alam: Perspektif Hukum Internasional. Padjadjaran Jurnal Ilmu Hukum, 1(2), 322-345.

Nurhayati, \& Erren, L. (2013). Kajian Hukum Terhadap Camat Sebagai Pejabat Pembuat Akta Tanah (PPAT) Sementara Ditinjau Dari Peraturan Pemerintah Nomor 37 Tahun 1998 Tentang Peraturan Pejabat Pembuat Akta Tanah. Yuriska: Jurnal Ilmiah Hukum, 5(1), 29-37.

Sihombing, L. (2014). Toll Road Infrastructure Development in Indonesia: A System Dynamics Perspective. 32nd International Conference of the System Dynamics Society. Delft.

Subakti, B. (2017). Pemanfaatan Foto Udara UAV untuk Pemodelan Bangunan 3D dengan Metode Otomatis. Jurnal Spectra, 15(30), 15-30.

Sridhar, U., \& Mandyam, S. (2009). On Structured BuyerSeller Negotiation for Agricultural Land Acquisition - Simulation Experiments with Rule-Based Models and Utility Functions. Asia-Pacific Development Journal, 16(2), 1-30. 